\title{
Jan-Peter Voß and Richard Freeman (eds.) (2016) Knowing Governance: The Epistemic Construction of Political Order. Basingstoke: Palgrave Macmillan. 300 pages. ISBN:978-1-137-51449-3
}

\author{
Jannick Schou \\ janh@itu.dk
}

Knowledge matters to governance. What counts as authoritative, legitimate and truthful knowledge matters to how political orders and collectivities are oriented and assembled. While this has been acknowledged for quite some time, the actual practices, instruments and actors involved in the production and stabilization of certain ways of knowing governance has received relatively less attention. Knowing Governance: The Epistemic Construction of Political Order provides a forceful argument for why this current neglect should be rectified. Split into five parts and twelve individual chapters, the anthology demonstrates why and how STS scholars can engage with the production of political knowledges. It shows why knowing governance might be central to understanding contemporary forms of governance as such.

"[W]e want to know governance through the ways it is made known to those who govern" (p. 2) Voß and Freeman, the editors of the volume, state in their introductory chapter. According to them, this requires a sensitivity towards the ways in which knowledge of governance is produced and constructed in the making. "Knowing governance", the productive conceptual device offered by the editors to cover such processes, means looking at the "formalizations and developments of ways of knowing how to do politics" (p. 2), and "the production and mobilization of ways of knowing about governance" (p. 3). Based firmly in the field of STS, this implies studying how particular collectivities, actors, models, metrics, standards, technologies, and instruments become enrolled in the production of knowledge about governance. It means paying attention to how certain representations of reality are made authoritative and legitimate through distributed decision-making processes. In this way, knowing governance serves as a methodological corrective to otherwise reified, instrumental, and neutralized accounts of political knowledge and knowledge of governance. These conceptual coordinates are developed in subsequent chapters through a number of empirical studies. Covering a wealth of different settings, from the European Union and global anti-piracy groups to the OECD and 'citizen panels', each chapter carefully unpacks the practices involved in knowing governance. Although the contributions are generally of a high quality, three chapters should be highlighted as particularly productive.

Chapter 4 by Christian Bueger draws on detailed fieldwork conducted as a part of a Lessons Learned Project intended to document knowledge on governance in the case of the Contact Group on Piracy off the Coast of Somalia; an international forum created to counter-act piracy off the coast of Somalia. Describing the Group as a 'laboratory' conducting 'experiments' in order to "compile facts and information" (p. 95), Bueger shows how it connects otherwise disparate sites into a relatively stable collective and is able to circulate its 
selective representations of piracy through the use of official strategic documents, the communiqué. Turning to the Project that Bueger played a pivotal role in himself, he recounts the immensely difficult, and oftentimes overtly 'failed' attempts to produce knowledge of and with global governance. In bringing the porous boundaries between academic and political laboratories to the front, the chapter provides a rich narrative of the oftentimes messy realities of doing and knowing governance.

Chapter 5 by Holger Strassheim and RebeccaLea Korinek turns to a study of behavioral science within the UK. These authors set out to investigate an empirical puzzle: why and how behavioral science, epitomized by the Behavioral Insights Team (BIT) in the UK, "has gained such a remarkable reputation" (p. 110)? Focusing on the practices through which "behavioral approaches became authorized and legitimized" (p. 110), they provide a compelling account of how these methods have managed to shape contemporary ways of knowing governance. They showcase how BIT (and similar organizations) have "cultivated politico-epistemic authority by claiming the role of 'choice architects', mobilizing easily demonstrable forms of evidence and modelling the policy process after experimental designs" (p. 121). These ideas have simultaneously been imported within discourses about the 'Big Society' promoted by political parties in the UK. In this way, behavioral science has become a core component within "sociotechnical imaginaries about future state-citizen relationships" (p. 121). Due to this 'double reading', focusing both on the establishment of political authority and the translation of ideas across institutional boundaries, the chapter produces exciting insights into how knowledge is legitimized, circulated, and translated across different sites.

Finally, chapter 10 by Brice Laurent looks at 'boundary-making' through a study of the OECD and the report on 'Public Engagement in Nanotechnology' it produced in 2012. Tracing the complex practices involved in producing the report, Laurent shows how demarcations "between 'technical' and 'policy' expertise, between 'expertise' and 'normative judgement"' (p. 231) are central to its making. The group in charge of the report continuously had to distinguish, delineate and demarcate its area of concern in order to balance different national agendas and organizational divisions of labor. In this sense, boundaries result from continuous processes of 'purification', which "ensure that reports are written as they are supposed to, that questions are answered the right way, and that projects are presented appropriately during plenary meetings" (p. 231). The chapter demonstrates how a specific case may provide "empirical lenses into processes of international ordering" (p. 232). In this way, the study showcases practices of international governance often left in the dark.

Laurent's chapter is also productive because it hints at a topic that remains unaddressed throughout the book, namely how the production of certain knowledges also implies invisibilities, exclusions, deviances, and 'monsters'. He thus argues that "purification allows the OECD to render invisible both the politics of technical expertise and the potential redefinitions of governance practices with emerging technologies" (p. 232). Yet, the role of such invisibilities is all too often rendered invisible in the book. But how does the making of certain knowledges about governance render other knowledges invisible, silenced and illegitimate? How might certain ways of knowing governance bring peripheralizations and exclusions into being (and vice versa)? And, we could ask in a more political register, how are contemporary forms of ghettoization, incarceration, and ethno-racial stigmatization linked to certain ways of knowing governance? Can we simply see these as unforeseen 'side-effects' of governmental practices or are they at the core of current ways of knowing how to govern by those who govern? Addressing such questions would have allowed the link between knowing and ordering to emerge more clearly, highlighting the consequences and impact of certain ways of knowing governance. While the book does shed light on "governance through the ways it is made known to those who govern", it has comparatively less to say on what such knowledges do. What happens to the pirates off the coast of Somalia? How is behavioral science used to govern, discipline and recast citizens? Put more simply: why is knowing governance different from knowing other settings and practices? 
Attending to such questions could have provided a bridge to the overlapping concerns of scholars within e.g. Foucauldian governmentality studies. While the editors do use a considerable amount of space in the introduction on connecting the present work with governmentality and interpretive policy studies, this cross-disciplinary dialogue fades out within large parts of the volume. However, a discussion of the book's theoretical, methodological and empirical implications for the wider study of governance could have amplified its impact significantly.
These caveats aside, Knowing Governance provides an in many ways impressive collection of work. It manages to intervene in current discussions in thoughtful ways, and offers useful conceptual devices for understanding the epistemic construction of knowledge. Despite a diversity of empirical sites, the book is held together by a firm thematic focus. This is a major strength of this work. While the book leaves certain questions open, it manages to provide a cogent argument for its overarching goal, namely to establish knowing governance as an exciting research agenda going forward. 